\title{
Soluble inflammatory markers as predictors of virological response in patients with chronic hepatitis $C$ virus infection treated with interferon- $\alpha$ plus ribavirin
}

\author{
Alexandre Sampaio Moura ${ }^{1 /+}$, Ricardo Andrade Carmo ${ }^{2}$, Antonio Lucio Teixeira ${ }^{1}$, \\ Mauro Martins Teixeira', Manoel Otávio da Costa Rocha ${ }^{1}$ \\ 1Programa de Pós-graduação em Infectologia e Medicina Tropical \\ ${ }^{2}$ Centro de Treinamento e Referência em Doenças Infecciosas e Parasitárias Orestes Diniz, Faculdade de Medicina, \\ Universidade Federal de Minas Gerais, Av. Alfredo Balena 190, 30130-100 Belo Horizonte, MG, Brasil
}

\begin{abstract}
The host immune response plays an important role in viral clearance in patients who are chronically infected with hepatitis $C$ virus $(H C V)$ and are treated with interferon and ribavirin. Activation of the immune system involves the release of pro and anti-inflammatory molecules that can be measured in plasma samples. The present study aimed to evaluate the association between pretreatment plasma levels of chemokines and soluble tumor necrosis factor receptors (sTNF-R) and the virological response in treated patients with chronic hepatitis C infection. Forty-one chronicallyinfected HCV patients that were being treated with interferon- $\alpha$ (IFN- $\alpha)$ plus ribavirin were included in the study. Socio-demographic, clinical and laboratory data were collected and pretreatment plasma levels of chemokine CCL2, CCL3, CCL11, CCL24, chemokine CXCL9, CXCL10, sTNF-R1 and STNF-R2 were measured. The virological response was assessed at treatment week 12, at the end of treatment and 24 weeks after treatment. Pretreatment CXCL10 levels were significantly higher in patients without an early virological response (EVR) or sustained virological response (SVR) compared to responders [512.9 pg/mL vs. $179.1 \mathrm{pg} / \mathrm{mL}(p=0.011)$ and $289.9 \mathrm{pg} / \mathrm{mL} \mathrm{vs.} 142.7 \mathrm{pg} / \mathrm{mL}(\mathrm{p}=0.045)$, respectively]. The accuracy of CXCL10 as a predictor of the absence of EVR and SVR was 0.79 [confidence interval (CI) 95\%: 0.59-0.99] and 0.69 (CI 95\%: 0.51-0.87), respectively. Pretreatment plasma levels of the other soluble inflammatory markers evaluated were not associated with a treatment response. Pretreatment CXCL10 levels were predictive of both EVR and SVR to IFN- $\alpha$ and ribavirin and may be useful in the evaluation of candidates for therapy.
\end{abstract}

Key words: hepatitis C - chemokines - tumour necrosis factor receptors - interferon-alpha

Hepatitis $\mathrm{C}$ virus (HCV) is estimated to infect around 170 million people worldwide and is one of the main causes of chronic liver failure (Brown \& Gaglio 2003). Combined treatment with interferon and ribavirin has been shown to interrupt fibrogenesis and can even reverse liver fibrosis when a sustained virological response (SVR) is obtained (Poynard et al. 2002). Unfortunately, the response rates are low, especially among genotype 1 infected patients, older patients and patients with advanced liver fibrosis (Manns et al. 2001, Fried et al. 2002, Lee et al. 2002, Mihm et al. 2006, Yamada et al. 2008). Identifying appropriate candidates for treatment is desirable due to the high cost and potentially serious adverse effects of the current therapy.

Treatment for chronic hepatitis $\mathrm{C}(\mathrm{CHC})$ patients currently consists of a combination of interferon- $\alpha$ (IFN- $\alpha$ ) and ribavirin for 24 or 48 weeks depending on the viral genotype (Strader et al. 2004, de Araújo et al. 2007). Exogenous IFN- $\alpha$ acts similarly to its endogenous counterpart through induction of the IFN-stimulated genes responsible for establishing an antiviral state within the

Financial support: CNPq, FAPEMIG

+ Corresponding author: alexandresmoura@gmail.com

Received 15 May 2010

Accepted 5 October 2010 cell (Tilg 1997, Feld \& Hoofnagle 2005). In addition to its direct antiviral activity, IFN- $\alpha$ strengthens both innate and adaptive immune responses through interactions with $\mathrm{T}$ lymphocytes, natural killer cells and dendritic cells (Tilg 1997). Ribavirin, a guanosine-analogue, seems to work as an antiviral agent mainly by inducing $\mathrm{HCV}$ mutagenesis, which results in a lower replicative profile (Feld \& Hoofnagle 2005). Ribavirin also acts as an immunomodulator, enhancing type $1 \mathrm{~T}$ helper cell (Th)-1 cytokine secretion and altering the Th1/Th2 balance in favor of a Th1 response (Tam et al. 1999).

SVRs [i.e., negative $\mathrm{HCV}$ qualitative polymerase chain reaction (PCR) 24 weeks after the end of treatment] are observed in approximately half of the treated patients and many factors, such as age, genotype, viral load and body weight, are related to treatment outcome (Manns et al. 2001, Fried et al. 2002, Asselah et al. 2010). The outcome of HCV treatment seems also to depend on the ability of host cellular immune responses to control viral replication. An early Th1 response is key for viral clearance during acute HCV infection (Guidotti \& Chisari 2001, Kamal et al. 2004, Rehermann \& Nascimbeni 2005) and an enhanced HCV-specific T-cell response is also associated with treatment response in chronically infected patients (Nelson et al. 1998, Cramp et al. 2000, Kamal et al. 2002, 2004). Therefore, it is reasonable to suppose that pretreatment levels of cytokines, especially those involved in the Th1 response, may predict treatment outcome. 
Chemokines, a subgroup of small cytokines, are involved in leukocyte trafficking through a process called haptotaxis, in which leukocytes move towards higher concentrations of chemokines (Baggiolini et al. 1997, Mackay 1997, Luster 1998, Kunkel 1999, Gerard \& Rollins 2001, Ono et al. 2003, Charo \& Ransohoff 2006). Chemokines are also involved in leukocyte activation, lymphocyte differentiation, regulation of the Th1/Th2 balance, angiogenesis and fibrogenesis (Charo \& Ransohoff 2006).

As the Th1 response is particularly involved in treatment responses of $\mathrm{CHC}$ patients, there is special interest in chemokines that are responsible for the recruitment of Th1 cells into the liver (Moura et al. 2009). The most important of these chemokines are CCL2 (monocyte chemotactic protein-1), CCL3 (macrophagic inflammatory protein 1 alpha), CCL4 (macrophagic inflammatory protein 1 beta), CCL5 (regulated upon activation, normal $\mathrm{T}$ cell expressed and secreted), CXCL9 (monokine induced by IFN-gamma) and CXCL10 (interferon-gamma inducible protein). The above mentioned CCL chemokines bind to $\mathrm{C}-\mathrm{C}$ chemokine receptor type 5 while the $\mathrm{CXCL}$ chemokines bind to $\mathrm{CXC}$ chemokine receptor type 3 (Bonecchi et al. 1998). In the liver, chemokines are mainly produced by activated monocytes, Kupffer cells, endothelial cells and hepatocytes (Koziel 1999, Apolinario Fernández de Sousa \& García Monzón 2003).

Another cytokine, tumor necrosis factor (TNF)- $\alpha$, does not affect HCV RNA or protein synthesis and, therefore, does not seem to be directly involved in HCV clearance (Frese et al. 2003). TNF synthesis is suppressed by IFN- $\alpha$ during HCV treatment (Abu-Khabar et al. 1992) and among patients treated with IFN- $\alpha$ and ribavirin, serum TNF- $\alpha$ levels significantly decreased at the end of treatment (Neuman et al. 2001). Soluble TNF- $\alpha$ receptors (sTNF-R), which are released by activated neutrophils, mononuclear blood cells and fibroblasts (Porteu et al. 1991, Lien et al. 1995) in response to mediators, such as interferon and TNF- $\alpha$ itself (Lantz et al. 1990, Joyce et al. 1994, Lien et al. 1995, Tilg et al. 1995), retain their ability to bind circulating TNF- $\alpha$ and are important in regulating its activity. These sTNF-R may contribute to the anti-inflammatory action of IFN- $\alpha$. In hepatitis B virus infection, elevated serum levels of sTNF-R before interferon therapy were found to predict a successful response to treatment (Marinos et al. 1995). In hepatitis C, the role of sTNF-R in predicting treatment responses is still not clear. Considering the characteristics of sTNF-R, including its greater stability in peripheral circulation, further studies are warranted to better understand the role of sTNF-R in predicting treatment responses.

We sought to investigate the association between peripheral pretreatment levels of several inflammatory markers, such as sTNF-R1 and sTNF-R2 and chemokines (CCL2, CCL3, CCL11, CCL24, CXCL9, CXCL10) and the virological response to IFN- $\alpha$ and ribavirin among patients with chronic HCV infection.

\section{PATIENTS, MATERIALS AND METHODS}

Patients - Between June 2005-December 2007, 41 consecutive patients with chronic hepatitis $\mathrm{C}$ infection who were submitted for treatment at the Orestes Diniz Cen- ter, a public university-based referral service for chronic hepatitis patients in Belo Horizonte, Minas Gerais, Brazil, were recruited for the study. All included patients were adults, had a positive anti-HCV antibody test [enzyme linked immunosorbent assay (ELISA)-3, Ortho Diagnostic Systems] and had HCV RNA that was detectable by PCR (AMPLICOR ${ }^{\circledR}$, Roche Molecular Systems) for more than six months. All patients had available liver biopsy samples with a length $\geq 1 \mathrm{~cm}$ and that contained at least five portal tracts, as evaluated by an independent, experienced liver pathologist using the METAVIR scoring system (Bedossa \& Poynard 1996). Patients were also negative for auto-antibodies (ANA, anti-mitochondria, anti-smooth muscle) and had negative results for Schistosoma mansoni ova on three stool samples. The mean age of the included patients was $44.4( \pm 11.11)$ years and 23 (56.1\%) were male. Moderate/severe liver inflammatory activity was present in $20(48.8 \%)$ patients, moderate/severe liver fibrosis (METAVIR $\mathrm{F} \geq 2$ ) was present in $28(68.3 \%)$ and cirrhosis (METAVIR F4) was present in $10(24.4 \%)$. Patients were excluded if they had previously used IFN- $\alpha$ with or without ribavirin or had any of the following: coinfection with HBV or HIV, chronic use of steroids or immunosuppressant drugs or renal failure. Socio-demographic, clinical and laboratory data were obtained through chart review and patient interview.

Treatment of CHC virus infection - The study treatment protocol followed Brazilian national guidelines for treatment of $\mathrm{HCV}$ infection that were available at the time (MS 2002). According to the guidelines, genotype 1-infected patients received a 48-week regimen of subcutaneous peg-IFN- $\alpha$ [either peg-IFN- $\alpha-2 \mathrm{a}(180 \mathrm{mcg} / \mathrm{week})$ or peg- IFN- $\alpha-2 b(1.5 \mathrm{mcg} / \mathrm{kg} / \mathrm{week})]$, at the physician's discretion) plus weight-based oral ribavirin $(1000 \mathrm{mg}$ /day for patients weighing less than $75 \mathrm{~kg}$ and $1250 \mathrm{mg} /$ day for those weighting $75 \mathrm{~kg}$ or more). Patients with genotype 2 or $3 \mathrm{HCV}$ infection received a 24-week regimen of subcutaneous IFN- $\alpha$ ( 3 mega units 3 times a week) plus the same weight-based oral ribavirin mentioned previously.

To assess early virological response (EVR), all genotype 1 patients had their HCV RNA quantified in plasma samples before treatment and at treatment week 12 using a PCR assay (AMPLICOR ${ }^{\circledR}$, Roche Molecular Systems, with detection limits of $600 \mathrm{IU} / \mathrm{mL}$ and $850,000 \mathrm{IU} / \mathrm{mL}$ ). Those patients without an EVR (i.e., without a drop in viral load of at least 2 logs at treatment week 12) had their treatment interrupted. Patients with genotypes 2 and 3 were treated for 24 weeks with no interim quantitative assessment of HCV viral load.

Chemokines and sTNF-R quantification - Plasma samples were taken from patients before starting therapy, at treatment week 12 (only for patients with HCV genotype 1 infection) and 24 weeks after treatment completion and were frozen at $-70^{\circ} \mathrm{C}$ until measurements were performed. For chemokine analysis, plasma samples were thawed and excess proteins, mainly albumin, were removed by acid/salt precipitation (Sousa-Pereira et al. 2006). Briefly, an equal volume of plasma and $1.2 \%$ trifluoroacetic acid/1.35 M NaCl were mixed and left at room temperature for $10 \mathrm{~min}$. Samples were then centrifuged 
for $5 \mathrm{~min}$ at $3000 \mathrm{~g}$ and the supernatants were adjusted for salt content $(0.14 \mathrm{M}$ sodium chloride and $0.01 \mathrm{M}$ sodium phosphate) and $\mathrm{pH}$ (7.4) for the determination of chemokine and sTNF-R levels. For sTNF-R measurement, samples were diluted in phosphate buffered saline.

Plasma concentrations of chemokines and STNF-R were measured using sandwich ELISA kits for CCL2, CCL3, CCL11, CCL24, CXCL9, CXCL10, sTNF-R1 and sTNF-R2 (DuoSet, R\&D Systems, Minneapolis, MN, USA), according to the manufacturer's instructions. The detection limits were $10 \mathrm{pg} / \mathrm{mL}$ for chemokines and 5 $\mathrm{pg} / \mathrm{mL}$ for sTNF-R. All samples were assayed in duplicate on the same plate.

Statistical analysis - Non-parametric analyses were performed using the Kruskal-Wallis test to compare median levels of soluble inflammatory markers between patients with or without SVRs. For those with genotype 1 infection, a comparison was also made between those with and without EVR. The receiver operator characteristic curve was used to evaluate the accuracy of soluble inflammatory markers to predict a virological response. The outcomes assessed were both EVR and SVR for patients with genotype 1 infection, whereas only the SVR was assessed for those with genotype 2 or 3 infection.

Statistical analysis was performed using the SPSS software package (version 12.0, SPSS Inc, Chicago, IL, USA). All reported $\mathrm{p}$ values are 2 -sided and statistical significance was set at $\mathrm{p}<0.05$.

Ethical approval - The study was approved by ethical committees at the Federal University of Minas Gerais and was performed in accordance with the ethical standards outlined in the Declaration of Helsinki.

\section{RESULTS}

Of the 41 patients included in the study, 29 (70.7\%) had a genotype 1 infection, 29 (70.7\%) had alanine aminotransferase greater than 1.5 times the normal upper limit and $28(68.3 \%)$ had moderate/severe liver fibrosis, including $10(24.4 \%)$ with cirrhosis. Pretreatment HCV viral load was assessed among those with genotype 1 infections and $16(57.1 \%)$ had levels greater than $600,000 \mathrm{IU} / \mathrm{mL}$. Of patients with genotype 1 infection, eight were treated with peg-IFN- $\alpha-2 a$ and 21 with peg-IFN- $\alpha-2 b$ and both treatments included weight-based ribavirin. All patients with genotype 2 or 3 infections were treated with conventional IFN- $\alpha$ combined with weight-based ribavirin. EVR was observed in $69 \%$ of patients infected with genotype 1. Global SVR was $55.3 \%$ and was greater among those infected with genotype 2 compared to those infected with genotype 1 or $3(100 \%, 57.1 \%$ and $46.2 \%$, respectively). Three patients were excluded from the SVR analysis: two abandoned treatment after week 12 and one interrupted treatment at week 16 due to severe anemia.

Analysis of the association between pretreatment levels of soluble inflammatory markers and virological response showed that elevated CXCL10 levels were associated with a lack of both EVR $(p=0.011)($ Table I $)$ and SVR $(p=0.045)$ (Figs 1, 2, Tables I, II). The accuracy of plasma CXCL10 levels to predict a lack of EVR was 0.79 [confidence interval (CI) $95 \%: 0.59-0.99$ ], with a sensitivity of $78 \%$ and $65 \%$ specificity of lack of EVR using $220 \mathrm{pg} / \mathrm{mL}$ as the cut-off point. Using a lower cut-off point of $150 \mathrm{pg} / \mathrm{mL}$ and an upper cut-off level of $450 \mathrm{pg} / \mathrm{mL}$ for predicting EVR yielded a positive predictive level and a negative predictive level of $85.7 \%$ and $71.4 \%$, respectively; in this setting, 15 (51.7\%) patients presented with CXCL10 plasma levels between $150-450 \mathrm{pg} / \mathrm{mL}$ and could not be classified.

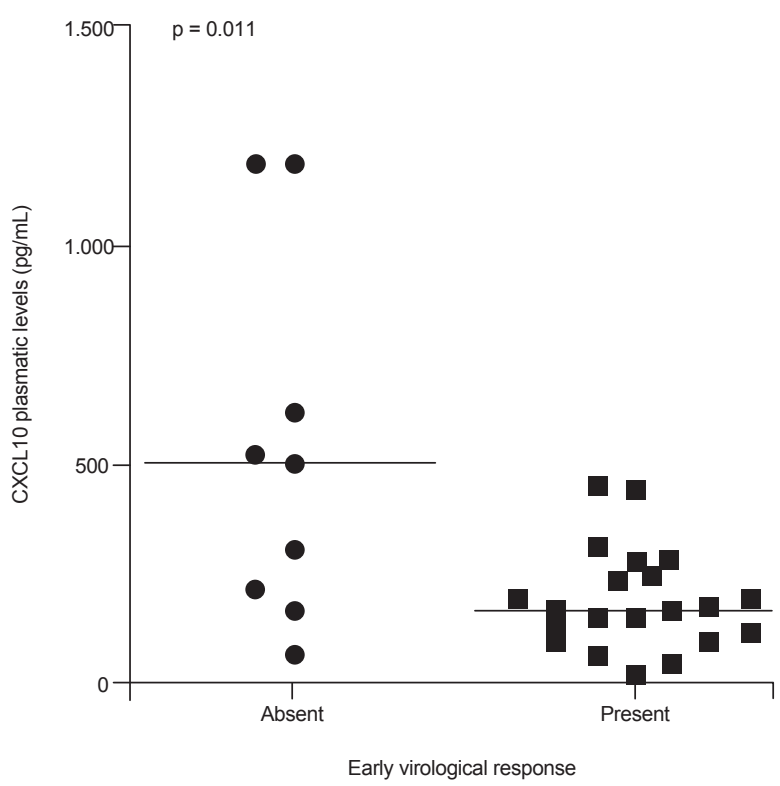

Fig. 1: pretreatment plasma levels of CXCL10 among patients with chronic hepatitis $\mathrm{C}$ infection treated with interferon- $\alpha$ plus ribavirin stratified by early virological response. $\mathrm{p}$ values presented as calculated with Mann-Whitney U-test.

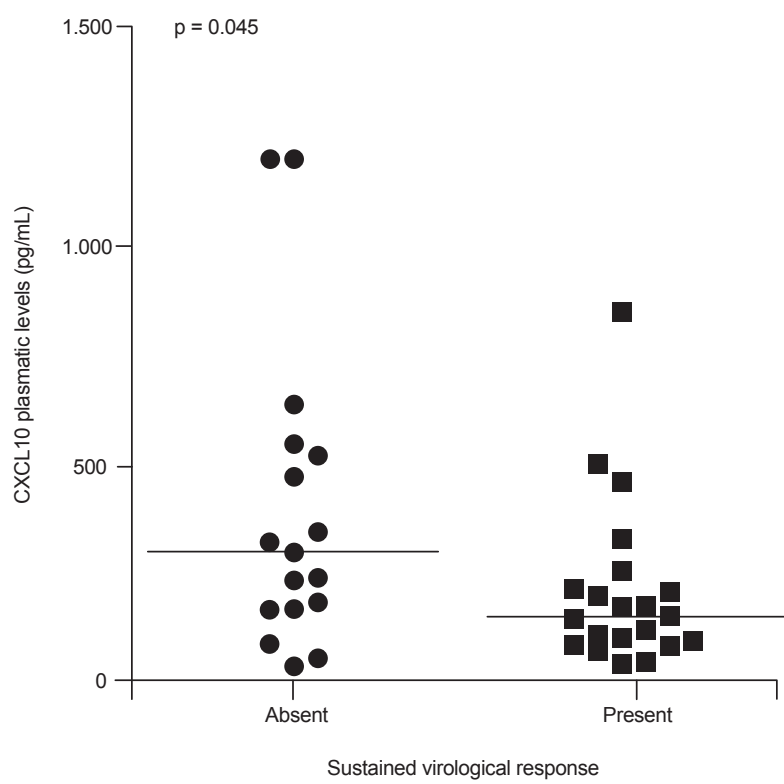

Fig. 2: pretreatment plasma levels of CXCL10 among patients with chronic hepatitis $\mathrm{C}$ infection treated with interferon- $\alpha$ plus ribavirin stratified by sustained virological response. $p$ values presented as calculated with Mann-Whitney U-test. 


\section{TABLE I}

Comparison of median and interquartile range pretreatment levels of soluble inflammatory markers $(\mathrm{pg} / \mathrm{mL})$ among treated chronic hepatitis $\mathrm{C}$ patients with and without early virological response (EVR)

\begin{tabular}{lccc}
\hline Inflammatory marker & $\begin{array}{c}\text { Without EVR } \\
(\mathrm{n}=9)\end{array}$ & $\begin{array}{c}\text { With EVR } \\
(\mathrm{n}=20)\end{array}$ & $\mathrm{p}$ value \\
\hline CCL2 & $124.5(85.5-177.8)$ & $122.7(36.2-133.3)$ & 0.627 \\
CCL3 & $141.1(89.1-207.6)$ & $100.9(5.0-126.9)$ & 0.340 \\
CCL11 & $259.1(239.4-304.9)$ & $216.6(168.0-273.0)$ & 0.183 \\
CCL24 & $690.4(346.2-1050.1)$ & $686.6(429.5-1228.6)$ & 0.945 \\
CXCL9 & $434.4(102.5-1711.0)$ & $637.2(2.5-1208.4)$ & 0.729 \\
CXCL10 & $512.9(225.5-630.3)$ & $179.1(107.2-268.9)$ & 0.011 \\
STNF-R1 & $721.7(636.7-996.7)$ & $824.6(537.3-1064.9)$ & 0.982 \\
sTNF-R2 & $2078.0(1992.8-2947.1)$ & $2411.0(1837.6-2657.8)$ & 0.594 \\
\hline
\end{tabular}

CCL2: monocyte chemotactic protein-1; CCL3: macrophagic inflammatory protein 1 alpha; CCL11: eotaxin-1; CCL24: eotaxin-2; CXCL9: monokine induced by IFN-gamma; CXCL10: interferon-gamma inducible protein; sTNF-R: soluble tumor necrosis factor receptors.

TABLE II

Comparison of median and interquartile range pretreatment levels of soluble inflammatory markers $(\mathrm{pg} / \mathrm{mL})$ among treated chronic hepatitis $\mathrm{C}$ patients with and without sustained virological response (SVR)

\begin{tabular}{lccc}
\hline Inflammatory marker & $\begin{array}{c}\text { With SVR } \\
(\mathrm{n}=17)\end{array}$ & $\begin{array}{c}\text { Without SVR } \\
(\mathrm{n}=21)\end{array}$ & $\mathrm{p}$ value \\
\hline CCL2 & $120.9(85.5-177.8)$ & $124.5(53.8-135.1)$ & 0.728 \\
CCL3 & $103.3(89.1-207.6)$ & $108.0(0-169.5)$ & 0.561 \\
CCL11 & $239.4(174.4-273.1)$ & $220.1(167.9-265.6)$ & 0.504 \\
CCL24 & $806.5(610.4-1050.1)$ & $690.5(390.0-1132.0)$ & 0.581 \\
CXCL9 & $626.5(102.5-1273.6)$ & $583.7(158.7-884.0)$ & 0.486 \\
CXCL10 & $289.9(157.7-512.9)$ & $142.7(86.7-206.6)$ & 0.045 \\
STNF-R1 & $721.7(636.7-996.7)$ & $613.4(498.3-1049.6)$ & 0.622 \\
STNF-R2 & $2078.0(1808.5-2683.4)$ & $2328.7(1910.0-2632.2)$ & 1.0 \\
\hline
\end{tabular}

sTNF-R: soluble tumor necrosis factor receptors.

The accuracy of CXCL10 plasma levels was lower for predicting SVR (0.69; CI 95\%: 0.51-0.87). Applying the same cut-off values used in the evaluation of EVR (i.e., $150 \mathrm{pg} / \mathrm{mL}$ and $450 \mathrm{pg} / \mathrm{mL}$ ), positive and negative predictive values for achieving SVR were $78.6 \%$ and $66.7 \%$, respectively. Fifteen $(39.5 \%$ ) patients presented with CXCL10 plasma levels between $150-450 \mathrm{pg} / \mathrm{mL}$ and could not be classified using these cut-off points.

Only four patients had CXCL10 plasma levels greater than $600 \mathrm{pg} / \mathrm{mL}$. Among this small group of patients, global SVR was $25 \%$ and the only responder had a genotype 2 infection.

The other soluble inflammatory markers assessed were not associated with therapeutic response (Tables I, II).

\section{DISCUSSION}

We showed that pretreatment plasma levels of CXCL10 were inversely correlated with response to treatment with IFN- $\alpha$ and ribavirin in patients with hepatitis $\mathrm{C}$ infection.
Although this finding has been reported by other authors (Narumi et al. 1997, Apolinario et al. 2004, Butera et al. 2005, Diago et al. 2006, Lagging et al. 2006, Romero et al. 2006), their results were based on the analysis of patients treated in the well-controlled context of clinical trials; our study strengthens the evidence for an association between CXCL10 levels and virological response among patients with $\mathrm{CHC}$ infection by showing an elevated negative predictive value in a real-life clinical setting.

In addition, our study did not show an association between plasma levels of the CC chemokines evaluated (CCL2, CCL3, CCL11, CCL24) and of sTNF-R with virological response. We did not find studies in the literature evaluating the association between peripheral levels of these other inflammatory markers and treatment response among patients with $\mathrm{CHC}$.

Apolinario et al. (2004) were the first to point out the association between serum levels of CXCL10 and therapeutic response. Accuracy of CXCL10 in predicting lack 
of SVR was 0.74 , which is slightly higher than that found in our study (0.69; CI 95\%: 0.51-0.87). Using a cut-off point of $299 \mathrm{pg} / \mathrm{mL}$ for predicting lack of virological response, Apolinario et al. (2004) found a sensitivity and specificity of $80 \%$ and $63 \%$, respectively, which was very similar to that found in our study ( $78 \%$ and $65 \%$, respectively).

Lagging et al. (2006) stratified patients into three groups according to pretreatment CXCL10 levels (0-150 pg/mL; 150-600 pg/mL; > $600 \mathrm{pg} / \mathrm{mL})$. Levels greater than $600 \mathrm{pg} / \mathrm{mL}$ had a negative predictive value for SVR of $79 \%$. In a subanalysis including only difficult to treat patients (i.e., elevated body mass index or high viral load) with high CXCL10 levels, none of the seven patients achieved SVR. In our study, of the four patients with levels greater than $600 \mathrm{pg} / \mathrm{mL}$, only one genotype 2 infected patient achieved SVR.

Different theories have been presented to explain the relationship between elevated levels of CXCL10 and poor response rates. High peripheral levels of CXCL10 could impair local CCL5 or CXCL10 gradient signaling (Butera et al. 2005) or could downregulate CXCR5 receptors in circulating CTL (Larrubia et al. 2007). Other authors (Diago et al. 2006) propose that elevated CXCL10 levels may result in an accumulation of effector $\mathrm{T}$ cells in the liver and the selective pressure imposed by this accumulation may foster outgrowth of immune escape HCV mutants that would be more difficult to eradicate with combined therapy (Diago et al. 2006). The observed association between CXCL10 levels and therapeutic response was not mediated by liver histological changes, as plasma levels of this chemokine were not associated with liver inflammatory activity or fibrosis in a subanalysis of the dataset (Moura et al. 2010).

CXCL9, which binds the same chemokine receptor as CXCL10 (i.e., CXC3), did not show an association with virological response in our study, in accordance with findings from a previous study conducted by Butera et al. (2005). Although acting in similar cells, a different regulation mechanism for this chemokine may explain this apparent inconsistency.

The small number of treated patients in our study limits the interpretation of the lack of an association between some of the inflammatory markers evaluated and virological response. Another limitation of our study was the evaluation of EVR only for genotype 1 infected patients; therefore, the association found between CXCL10 levels and EVR cannot be extrapolated to patients infected by other HCV genotypes.

In summary, we have shown that pretreatment plasma levels of CXCL10 were associated with virological response among patients with $\mathrm{CHC}$ infection. Due to the high negative predictive value of elevated pretreatment CXCL10 levels, their assessment may be useful in the evaluation of potential candidates for therapy with interferon and ribavirin.

\section{ACKNOWLEDGEMENTS}

To Dr Dora Mendez del Castillo and Nara de Oliveira Carvalho, from the Molecular Biology Laboratory at the Núcleo de Ações e Pesquisa em Apoio Diagnóstico (NUPAD), Federal University of Minas Gerais, for storing and processing the plasma samples.

\section{REFERENCES}

Abu-Khabar KS, Armstrong JA, Ho M 1992. Type I interferons (IFNalpha and -beta) suppress cytotoxin (tumor necrosis factor-alpha and lymphotoxin) production by mitogen-stimulated human peripheral blood mononuclear cell. J Leukoc Biol 52: 165-172.

Apolinario A, Diago M, Lo Iacono O, Lorente R, Pérez C, Majano PL, Clemente G, García-Monzón C 2004. Increased circulating and intrahepatic T-cell-specific chemokines in chronic hepatitis $\mathrm{C}$ : relationship with the type of virological response to peginterferon plus ribavirin combination therapy. Aliment Pharmacol Ther 19: 551-562.

Apolinario Fernández de Sousa A, García Monzón C 2003. Role of chemokines in the pathogenesis of liver diseases. Rev Esp Enferm Dig 95: 614-620.

Asselah T, Estrabaud E, Bieche I, Lapalus M, De Muynck S, Vidaud M, Saadoun D, Soumelis V, Marcellin P 2010. Hepatitis C: viral and host factors associated with non-response to pegylated interferon plus ribavirin. Liver Int 30: 1259-1269.

Baggiolini M, Dewald B, Moser B 1997. Human chemokines: an update. Annu Rev Immunol 15: 675-705.

Bedossa P, Poynard T 1996. An algorithm for the grading of activity in chronic hepatitis C. The METAVIR Cooperative Study Group. Hepatology 24: 289-293.

Bonecchi R, Bianchi G, Bordignon PP, D’Ambrosio D, Lang R, Borsatti A, Sozzani S, Allavena P, Gray PA, Mantovani A, Sinigaglia F 1998. Differential expression of chemokine receptors and chemotactic responsiveness of type $1 \mathrm{~T}$ helper cells (Th1s) and Th2s. J Exp Med 187: 129-134.

Brown RS Jr, Gaglio PJ 2003. Scope of worldwide hepatitis C problem. Liver Transpl 9: S10-13.

Butera D, Marukian S, Iwamaye AE, Hembrador E, Chambers TJ, Di Bisceglie AM, Charles ED, Talal AH, Jacobson IM, Rice CM, Dustin LB 2005. Plasma chemokine levels correlate with the outcome of antiviral therapy in patients with hepatitis C. Blood 106: 1175-1182.

Charo IF, Ransohoff RM 2006. The many roles of chemokines and chemokine receptors in inflammation. N Engl J Med 354: 610-621.

Cramp ME, Rossol S, Chokshi S, Carucci P, Williams R, Naoumov NV 2000. Hepatitis C virus-specific T-cell reactivity during interferon and ribavirin treatment in chronic hepatitis C. Gastroenterology 118: 346-355.

de Araújo ES, Mendonça JS, Barone AA, Gonçales FL Jr, Ferreira MS, Focaccia R, Pawlotsky JM 2007. Consensus of the Brazilian Society of Infectious Diseases on the management and treatment of hepatitis C. Braz J Infect Dis 11: 446-450.

Diago M, Castellano G, García-Samaniego J, Pérez C, Fernández I, Romero M, Iacono OL, García-Monzón C 2006. Association of pretreatment serum interferon gamma inducible protein 10 levels with sustained virological response to peginterferon plus ribavirin therapy in genotype 1 infected patients with chronic hepatitis C. Gut 55: 374-379.

Feld JJ, Hoofnagle JH 2005. Mechanism of action of interferon and ribavirin in treatment of hepatitis C. Nature 436: 967-972.

Frese M, Barth K, Kaul A, Lohmann V, Schwärzle V, Bartenschlager $\mathrm{R}$ 2003. Hepatitis C virus RNA replication is resistant to tumour necrosis factor-alpha. J Gen Virol 84: 1253-1259.

Fried MW, Shiffman ML, Reddy KR, Smith C, Marinos G, Gonçales FL Jr, Häussinger D, Diago M, Carosi G, Dhumeaux D, Craxi A, Lin A, Hoffman J, Yu J 2002. Peginterferon alfa-2a plus ribavirin for chronic hepatitis C virus infection. N Engl J Med 347: 975-982.

Gerard C, Rollins BJ 2001. Chemokines and disease. Nat Immunol 2: $108-115$. 
Guidotti LG, Chisari FV 2001. Noncytolytic control of viral infections by the innate and adaptive immune response. Annu Rev Immunol 19: 65-91.

Joyce DA, Gibbons DP, Green P, Steer JH, Feldmann M, Brennan FM 1994. Two inhibitors of pro-inflammatory cytokine release, interleukin-10 and interleukin-4, have contrasting effects on release of soluble p75 tumor necrosis factor receptor by cultured monocytes. Eur J Immunol 24: 2699-2705.

Kamal SM, Fehr J, Roesler B, Peters T, Rasenack JW 2002. Peginterferon alone or with ribavirin enhances $\mathrm{HCV}$-specific CD4 T-helper 1 responses in patients with chronic hepatitis C. Gastroenterology 123: 1070-1083.

Kamal SM, Ismail A, Graham CS, He Q, Rasenack JW, Peters T, Tawil AA, Fehr JJ, Khalifa Kel S, Madwar MM, Koziel MJ 2004. Pegylated interferon alpha therapy in acute hepatitis C: relation to hepatitis $\mathrm{C}$ virus-specific $\mathrm{T}$ cell response kinetics. Hepatology 39: 1721-1731.

Koziel MJ 1999. Cytokines in viral hepatitis. Semin Liver Dis 19: 157-169.

Kunkel SL 1999. Through the looking glass: the diverse in vivo activities of chemokines. J Clin Invest 104: 1333-1334.

Lagging M, Romero AI, Westin J, Norkrans G, Dhillon AP, Pawlotsky JM, Zeuzem S, von Wagner M, Negro F, Schalm SW, Haagmans BL, Ferrari C, Missale G, Neumann AU, VerheijHart E, Hellstrand K 2006. IP-10 predicts viral response and therapeutic outcome in difficult-to-treat patients with $\mathrm{HCV}$ genotype 1 infection. Hepatology 44: 1617-1625.

Lantz M, Malik S, Slevin ML, Olsson I 1990. Infusion of tumor necrosis factor (TNF) causes an increase in circulating TNFbinding protein in humans. Cytokine 2: 402-406.

Larrubia JR, Calvino M, Benito S, Sanz-de-Villalobos E, Perna C, Pérez-Hornedo J, González-Mateos F, García-Garzón S, Bienvenido A, Parra T 2007. The role of CCR5/CXCR3 expressing $\mathrm{CD} 8^{+}$cells in liver damage and viral control during persistent hepatitis C virus infection. J Hepatol 47: 632-641.

Lee SS, Heathcote EJ, Reddy KR, Zeuzem S, Fried MW, Wright TL, Pockros PJ, Häussinger D, Smith CI, Lin A, Pappas SC 2002. Prognostic factors and early predictability of sustained viral response with peginterferon alfa-2a (40KD). J Hepatol 37: 500-506.

Lien E, Liabakk NB, Johnsen AC, Nonstad U, Sundan A, Espevik T 1995. Polymorphonuclear granulocytes enhance lipopolysaccharide-induced soluble p75 tumor necrosis factor receptor release from mononuclear cells. Eur J Immunol 25: 2714-2717.

Luster AD 1998. Chemokines-chemotactic cytokines that mediate inflammation. $N$ Engl J Med 338: 436-445.

Mackay CR 1997. Chemokines: what chemokine is that? Curr Biol 7: R384-386.

Manns MP, McHutchison JG, Gordon SC, Rustgi VK, Shiffman M, Reindollar R, Goodman ZD, Koury K, Ling M, Albrecht JK 2001. Peginterferon alfa-2b plus ribavirin compared with interferon alfa-2b plus ribavirin for initial treatment of chronic hepatitis $C$ : a randomised trial. Lancet 358: 958-965.

Marinos G, Naoumov NV, Rossol S, Torre F, Wong PY, Gallati H, Portmann B, Williams R 1995. Tumor necrosis factor receptors in patients with chronic hepatitis B virus infection. Gastroenterology 108: 1453-1463.

Mihm U, Herrmann E, Sarrazin C, Zeuzem S 2006. Review article: predicting response in hepatitis $\mathrm{C}$ virus therapy. Aliment Pharmacol Ther 23: 1043-1054.

Moura AS, Carmo RA, Teixeira AL, Leite VH, Rocha MO 2010. Soluble inflammatory markers as predictors of liver histological changes in patients with chronic hepatitis $\mathrm{C}$ virus infection. Eur J Clin Microbiol Infect Dis 29: 1153-1161.
Moura AS, Carmo RA, Teixeira AL, Rocha MO 2009. Soluble inflammatory markers as predictors of hepatocellular damage and therapeutic response in chronic hepatitis C. Braz J Infect Dis 13: 375-382.

MS - Ministério da Saúde/Secretaria de Atenção à Saúde 2002. Portaria 863 de 04 de novembro de 2002. Protocolo clínico e diretrizes terapêticas para o tratamento da hepatite viral crônica $C$. Available from: http://www.saude.ms.gov.br/controle/ShowFile. php?id=2227.

Narumi S, Tominaga Y, Tamaru M, Shimai S, Okumura H, Nishioji K, Itoh Y, Okanoue T 1997. Expression of IFN-inducible protein-10 in chronic hepatitis. J Immunol 158: 5536-5544.

Nelson DR, Marousis CG, Ohno T, Davis GL, Lau JY 1998. Intrahepatic hepatitis $\mathrm{C}$ virus-specific cytotoxic $\mathrm{T}$ lymphocyte activity and response to interferon alfa therapy in chronic hepatitis C. Hepatology 28: 225-230.

Neuman MG, Benhamou JP, Malkiewicz IM, Akremi R, Shear NH, Asselah T, Ibrahim A, Boyer N, Martinot-Peignoux M, Jacobson-Brown P, Katz GG, Le Breton V, Le Guludec G, Suneja A, Marcellin P 2001. Cytokines as predictors for sustained response and as markers for immunomodulation in patients with chronic hepatitis C. Clin Biochem 34: 173-182.

Ono SJ, Nakamura T, Miyazaki D, Ohbayashi M, Dawson M, Toda M 2003. Chemokines: roles in leukocyte development, trafficking, and effector function. J Allergy Clin Immunol 111: 1185-1199.

Porteu F, Brockhaus M, Wallach D, Engelmann H, Nathan CF 1991. Human neutrophil elastase releases a ligand-binding fragment from the $75-\mathrm{kDa}$ tumor necrosis factor (TNF) receptor. Comparison with the proteolytic activity responsible for shedding of TNF receptors from stimulated neutrophils. J Biol Chem 266: 18846-18853.

Poynard T, McHutchison J, Manns M, Trepo C, Lindsay K, Goodman $\mathrm{Z}$, Ling MH, Albrecht $\mathrm{J}$ 2002. Impact of pegylated interferon alfa$2 \mathrm{~b}$ and ribavirin on liver fibrosis in patients with chronic hepatitis C. Gastroenterology 122: 1303-1313.

Rehermann B, Nascimbeni M 2005. Immunology of hepatitis B virus and hepatitis $\mathrm{C}$ virus infection. Nat Rev Immunol 5: 215-229.

Romero AI, Lagging M, Westin J, Dhillon AP, Dustin LB, Pawlotsky JM, Neumann AU, Ferrari C, Missale G, Haagmans BL, Schalm SW, Zeuzem S, Negro F, Verheij-Hart E, Hellstrand K 2006. Interferon (IFN)-gamma-inducible protein-10: association with histological results, viral kinetics, and outcome during treatment with pegylated IFN-alpha 2a and ribavirin for chronic hepatitis C virus infection. J Infect Dis 194: 895-903.

Sousa-Pereira SR, Teixeira AL, Silva LC, Souza AL, Antunes CM, Teixeira MM, Lambertucci JR 2006. Serum and cerebral spinal fluid levels of chemokines and Th2 cytokines in Schistosoma mansoni myeloradiculopathy. Parasite Immunol 28: 473-478.

Strader DB, Wright T, Thomas DL, Seeff LB 2004. Diagnosis, management, and treatment of hepatitis C. Hepatology 39: 1147-1171.

Tam RC, Pai B, Bard J, Lim C, Averett DR, Phan UT, Milovanovic T 1999. Ribavirin polarizes human $\mathrm{T}$ cell responses towards a Type 1 cytokine profile. J Hepatol 30: 376-382.

Tilg H 1997. New insights into the mechanisms of interferon alfa: an immunoregulatory and anti-inflammatory cytokine. Gastroenterology 112: 1017-1021.

Tilg H, Vogel W, Dinarello CA 1995. Interferon-alpha induces circulating tumor necrosis factor receptor p55 in humans. Blood 85: 433-435.

Yamada G, Iino S, Okuno T, Omata M, Kiyosawa K, Kumada H, Hayashi N, Sakai T 2008. Virological response in patients with hepatitis $\mathrm{C}$ virus genotype $1 \mathrm{~b}$ and a high viral load: impact of peginterferon-alpha-2a plus ribavirin dose reductions and hostrelated factors. Clin Drug Investig 28: 9-16. 